\title{
THE MUTUAL RECIPROCITY OF EDUCATION, NON-FORMAL CULTURAL EDUCATION AND SOCIAL CAPITAL
}

\author{
Edīte Igaune $^{1}$, Ilze Liepa-Balode ${ }^{2}$, Agnese Hermane ${ }^{3}$ \\ ${ }^{1}$ University College of Economics and Culture, Latvia, edite.igaune@inbox.lv \\ ${ }^{2}$ Latvian Academy of Culture, Latvia, *Corresponding author: ilzeliepa@inbox.lv \\ ${ }^{3}$ Latvian Academy of Culture, Latvia, agnese.hermane@lka.edu.lv
}

\begin{abstract}
Human knowledge and creative potential has become one of the most important driving forces of humanity progress. In the context of the twenty-first century, in order to create a high-quality culture environment, it requires a paradigm shift in education - the transition to education, which stimulates the imagination, intuition, emotions and creative ideas and develops critical thinking. Non-formal education and the skills and knowledge gained in it is still in evaluation and recognition phase in Latvia. It is still developing; therefore, it is important to create a clear understanding of the importance and social role of non-formal cultural education. The paper aims to explore the role of non-formal cultural education in strengthening social capital as well as to identify what social capital indicators can be attributed to non-formal cultural education programmes. The topicality of the study is determined by the fact that non-formal cultural education and social capital in the context of Latvia are little explored areas, as well as there is lack of research on mutual reciprocity. The study uses qualitative research methodology. Research analyses non-formal cultural education programmes of 10 subordinated institutions of Latvian Ministry of Culture (museums, theatres, concert institutions and opera) and on the basis of 19 in-depth and semi-structured interviews. Study contains new, theoretically based evaluation model of social capital and characterizes of indicators in the context of non-formal education. The study confirms that there is a mutual reciprocity between social capital and non-formal cultural education programmes, and these programmes have a positive and supportive role in strengthening both the individual and collective social capital.
\end{abstract}

Keywords: education; non-formal cultural education; social capital

Type of the paper: Empirical study, Theoretical paper

JEL Classification: I29; Z19

\section{Introduction}

Human knowledge and creative potential has become one of the most important driving forces of human progress. Cultural and art education is experiencing increasing pressure in relation to the variety of objectives to be achieved in addition to the task of ensuring knowledge of the arts. The importance of personal creativity development is increasingly appreciated in the field of education. Not without reason the word 'learning' has become a key word for the twenty-first century.

It is important to promote public involvement and active participation in cultural processes that promote lifelong self-development. Not only educational institutions deals with it but also cultural institutions, such as museums, theatres, opera and other cultural organizations, that offers a variety of non-formal educational activities and programmes for children, young people and adults. The abovementioned trend is more and more spreading out in Latvia, as the time in which we live states that in order to create qualitative culture environment, it requires a paradigm shift in education - the transition to an education that stimulates imagination, intuition, emotions and creative ideas develops critical thinking.

Non-formal education and the assessment and recognition of the acquired skills and knowledge are still under development in Latvia; therefore, it is essential to create a proper understanding of the 
social role of the non-formal cultural education and its significance not only in personal life but also for the country, in general.

Society is composed of individuals, and there is reciprocity, with social capital elements as a result of it - such as mutual relations, trust, informal network, cooperation; therefore, one of the most successful and valuable research tools is non-formal cultural evaluation in the context of social capital. Although there are still relatively few publications and studies on this form of capital in Latvia, the concept of 'social capital' in the world over the past 20 years has become one of the most common terms used in social studies. Not only many scholars have focused on this research, a significant contribution to social capital research has also been made by the World Bank.

The topicality of the study is determined, that is, the non-formal cultural education and social capital in the context of Latvia are little explored areas as well as there is lack of research on mutual reciprocity.

Main research question of the study is: whether there is a mutual reciprocity between social capital and non-formal cultural education in cultural organizations and which social capital elements, such as a set of indicators, refers to non-formal cultural programs. According to the key question of the study, the main goal is to investigate the significance of non-formal cultural education in strengthening social capital.

The study uses qualitative research methodology. Empirical part of the study includes 19 in-depth and semi-structured expert interviews of 10 subordinated institutions of the Latvian Ministry of Culture. The verification of study indicator model of social capital improves non-formal cultural education programmes that have a positive and supportive role in strengthening social capital in the individual and the society level.

\section{Literature Review}

Non-formal cultural education. In the Latvian education policy, policy planning and cultural policy documents have a clear distinction borders between formal and non-formal educations, but the terms 'non-formal cultural education' and 'non-formal cultural education programs' are not clearly defined. There are references to terms such as 'non-formal education', 'the informal education', 'adult education' and 'lifelong learning', which creates a fragmented impression and don't describe cultural institutions' educational programs. At the same time, in cultural policy documents, formal and nonformal cultural educations have an essential role in avoiding of public social degradation and in strengthening the importance of cultural institutions. Cultural education is mentioned as a long-term investment in creating human capital and social networking, what contribute to people's social and communication skills development, cooperation, social coherence, intergenerational communication and social integration (Law on Education (1998); Cultural Policy Guidelines 2014-2020 'Creative Latvia' (2014); National Development Plan 2014-2020 (2012); Sustainable Development Strategy of Latvia 'Latvia 2030', 2010).

By analysing the characteristics of non-formal education (goals, time, content, systems and control mechanisms), it can be concluded that non-formal education is much broader in activities than formal education (Smith, 2001; UNESCO. International Standard Classification of Education, Memorandum on Lifelong Learning, 2000) and the required skills, knowledge assessment and recognition of nonformal education are still in process of recognition. Therefore, it is essential to create a proper understanding of what is non-formal cultural education and explore its role in human life and in country as a whole.

Social capital. In the scientific literature, it often has an opinion that it is difficult to express summarizing conclusions about social capital because the approach to measuring and theoretical bases is different, sometimes even opposite. Generalizing the concept of social capital, it can be classified into two main groups or theoretical models.

Amongst the first group of theorists are Bourdieu (1986; 1989), who accentuates social capital as one of the forms of capital (in addition to the economic, cultural and symbolic). This model emphasises 
access to resources and balance of authority in society and stresses availability of political and economic resources through social contacts and networks (neo-marxism). The field of Bourdieu's theoretical analysis is individual behaviour and social structures reproduction as the result. Consequently, the social capital is viewed as an individual property as a resource that expand or limit his options.

The second theoretical model emphasises social norms and the abilities of individuals in condition of free market economy (the neo-liberal paradigm). The most outstanding representatives and theorists of this model - Coleman, (1966, 1990, 2013), Putnam (1993, 1996, 2000) and Fukuyama (1995) defined it as a phenomenon that occurs in social interaction and social networks. Thus, social capital is a property and resource of social group rather than individuals. It affects groups and shows its quality. This direction of researchers sees social capital as a phenomenon with a positive value - it promotes the development of social groups. This approach is related to the civil society concept and ideology of communitarianism. Other source of theoretical impact is the economic theory, what arise in the 1960s of the past century and introduced the concept of 'human capital' (Tzanakis, 2013; Daugavietis, 2015; Igaune 2012).

Authors of both theoretical models recognised that social capital in the production and reproduction is essential in cultural norms, which are rooted in traditions. In theory and research literature, the social capital attributed to the social development promoter strength; it can be an important resource of community, regional, national economic, political and social development (Woolcock \& Deepa, 2000; Lin, 1999).

Education, non-formal cultural education and social capital. By analysing a considerable amount of literature and sources, it can be concluded that there are some studies on education in conjunction with the social capital, but not directly attributable to research and theories about reciprocity of cultural education (formal and informal) with social capital. Therefore, in order to analyse non-formal cultural education and social capital interconnections, first, intercommunication between education and social capital must be assessed, mutual relevance and impact must be evaluated, but the conclusions about the non-formal cultural education has been taken over from the conclusions of education in general, especially, because the fundamentally social capital theoretical basis is rooted in Coleman's (2013) research carried out in 1988, which are amongst the first that in the context of social capital describes circumjacent environmental background (family; friends; social groups, such as sports and art clubs; etc.) essential role of the children success in school, as well as shows ambient environment as the important instrument in promotion of healthy, open personality, and illustrates the human and social capital in the operation and effects at the individual level. Coleman demonstrated strong correlations between parents' educational level (which is the main element in creating human capital) and a children's potential to build a strong social capital (Dijkstra, Veenstra and Peschar, 2004).

Similar to Coleman, Bourdieu (1989) associated social capital with individual or human capital. This is a resource of particular individual or a group and can regarded as productive, if it helps to increase the well-being of an individual or a group. Just as human capital, it can't be fully used. Likewise, the cultural education - both formal and informal levels, which in addition to the rules that are learned and transferred to the family, creating a cultural capital - which is Bourdieu's main object of the investigations, closely interacts with social capital.

Although studying and measuring social capital traditionally focuses on the impact of the economic aspects and benefits, there are also a number of work of scientists and specialists that studied the mutual interconnections of education and social capital, which emphasise the importance of education in strengthening social capital.

Putnam (1993) found that comparing social capital with economic success reveals a strong link between higher education for individuals and social capital. The income of higher educated individuals was higher, but social inequality in US states with high social capital is lower than that in others. Similarly, Harvard University study (Glaeser, Laibson \& Sacerdote, 2002) particularly discovers and highlights education as one of the key measures of social capital. By analysing social capital of community, it is concluded that individuals who work in jobs related with other people evaluate higher 
socially close and trusting relationship and devote more time to social relations at work and outside of it. The study also deals with education and ethnic homogeneity factors that are closely linked with formation of social capital. Higher education is correlated with higher levels of social capital, whilst the greater ethnic diversity mitigates it.

Two researchers of the World Bank (Knack, Keefer 1997) who conducted a study on the impact of social capital on growth arrived at similar conclusions. The study use indicators of trust and civic norms from the World Values Surveys for a sample of 29 country market economies. The study confirms that trust and civic norms and civic norms are stronger in nations with higher and more equal incomes, with institutions that restrain predatory actions of chief executives and with better educated and ethnically homogeneous populations. From which follows that the higher level of education is due to the trust, which is one of the most important indicators of social capital.

Another US scientist sociologist, Heller (1996), carried out a research on the state of Kerala, southern India, which in long term has showed the highest and most favourable figures of education, life expectancy and other areas. A study of several years showed that in this state, the main conductive element for developing social capital was state policy and guidelines, which created conditions that helped the different social groups to organise their collective interest. By researching the high educational performance, it was concluded that the state of Kerala education institutions operate at the same time as community centres and here, in addition to formal education, a variety of statesupported non-formal forms of learning, such as different interest clubs and craft classes, including a variety of cultural opportunities were also available. It shows that educational institutions become more effective if there is active and informed participation of other members of the community (parents, local groups, etc.). Heller emphasised that in a society where parents and local group show active interest in children's education and success, the teachers are more accountable for their work, but pupils get better grades and better used school equipment. In turn, the public who engage in nonformal forms of learning becomes more cohesive, favourable and supportive.

In 1997, Higgins and Loynes' study of outdoor learning opportunities in summer camp in Scotland where in addition to a summer internship training was also offered non-formal education opportunities showed that it is very effective to synthesise formal and non-formal cultural educations. This synthesis has positive impact on students' social capital; it forms fundamental values of life and personality strengthening, contributes interest to involve in various cultural and social organizations, and so on. The study points the fundamental role of the non-formal cultural education as ancillary in formal education and emphasises this mutual reciprocity as important instrument in strengthening social capital of young people

Similar to Loyn, two British sociologists Fester and Umberstone (2006) stressed non-formal learning environment as an autonomous field of training, which, within social integration, significantly enrich the environment of formal learning. Special emphasis is on mutual reciprocity and role of non-formal learning to expand citizen level of involvement and connection. Non-formal learning is also mentioned as strong instrument of social integration.

Iranian sociologist Sadegh Bafandeh Imandoust (2011) explored the continuing impact of social capital in 450 branches of the Iranian Payam-e-Noor University. He has concluded that, first of all, a focus on social capital allows authorities to consider the importance of non-material assets in social policy; second, researcher believes that the open distance education can affect the quality and quantity of beneficiaries and social capital in country. A focus on social capital allows for a closer examination of capacity of individuals and groups for making linkages amongst themselves and with organisations at the local or national level. Researcher stresses that this study opens new horizons for role of open distance learning in strengthening of social capital in individual and entire country level.

Similarly, Pelše (2007) studied the social capital development of Zemgale district in Latvia as one of the important recommendations put forward lifelong learning system. Pelše stressed that by strengthening and developing such forms of non-formal education establishment, local authorities will gain more knowledgeable citizens who will be able to use this knowledge in their daily and economical activity, generating additional income in their households and in the local districts. It would also affect the psychological climate improvement in the local community. The study also 
highlights the significance of non-formal education and close and consistent networking importance, because increasing social capital of individuals will focus more on areas around the educational institutions, which will participate in this process. It will be less pronounced in distant places, because the programme accessibility barrier requires greater initiative from an individual. Pelše concluded that the state can speed up the formation of social capital by supporting a variety of education institutions (also non-formal) in which social capital originally formed.

By resuming analysis of variety of authors, it can be concluded that education, and especially, nonformal education including non-formal cultural education, is in close, mutual reciprocity with strengthening of social capital. By contrast, breaking down the barriers between formal and nonformal educations is the next step in order to promote interaction and synergies between the different learning environments.

\section{Methodology}

The survey is based on qualitative research methodology. Developing the theoretical base of paper was used in the analysis of theoretical literature and secondary sources (various researches, legislation research related to education, non-formal cultural education and social capital, etc.).

Research include analysis of 37 non-formal cultural education programmes of 10 subordinated institutions of the Latvian Ministry of Culture (Art Museum RIGA BOURSE; Museum of Decorative Arts and Design; ARSENĀLS Exhibition Hall; Literature and Music museum; The Latvian National Symphony Orchestra; Latvijas Koncerti; Latvian National Opera and Ballet; Daile Theatre; Latvian National Theatre; M. Chekhov Riga Russian Theatre) - from October, 2014, till May, 2015.

Empirical part of the study includes 19 in-depth and semi-structured expert interviews with noninformal cultural education programme makers and managers. All experts were asked questions based on the guidelines developed by the interview. The key criteria for the selection of respondents for interviews were raised by the following factors: (1) represents one of the above-mentioned Ministry of Culture subordinate institutions; (2) personally involved in the creation and development of nonformal cultural education programme; (3) personally involved and works in direct contact with the non-formal cultural education programme visitors.

\section{Results}

As the terms 'non-formal cultural education' and 'non-formal cultural education programmes' are not clearly defined neither in the Latvian education policy nor in policy planning and cultural policy documents, in this study, the term 'non-formal cultural education' is defined as individual creativity, talent cultivation and obtaining knowledge and competences in the culture field outside the formal education, regardless of age and level of education. Whilst 'non-formal cultural education programmes' are ongoing educational programmes in cultural institutions, they are not included in the formal educational forms.

Education as such and non-formal education, in particular, including non-formal cultural education, is in close, mutual reciprocity associated with the strengthening of social capital. An individual can increase their capital in culture field by taking advantage of resources such as identification, communication, connections, prestige, dignity, identity, knowledge, education, well-being, selfrealization and self-confidence.

Social capital is an important and promoting resource in strengthening political and social development of communities, regions and states.

Social capital is generally understood as interpersonal (also inter-group, inter-institutional) network volumes and quality, together with related social norms. Social capital arises as the result of mutual relations between individuals. This is an existing or potential resource set, associated with long-term, more or less institutionalized relations networks, which are characterised by mutual familiarity, trust and interaction. 
Study authors in analysing non-formal cultural education programs use the theories of both the models, because culture consumption includes both individual and group impact.

Cultural education both in formal and non-formal aspects, as well as cultural consumption, is an integral part of the accepted norms of society, networking and civic participation, which is an important aspect of strengthening social capital. These social benefits are linked to each other and complemented by other cultural impact indicators, such as knowledge and skills, strengthening selfconfidence, promotion of cultural competence as well as cultural education.

Studying similarities of social capital and education primarily have to be seen by human capital analysis model and explored mutual reciprocity between these two forms of capital.

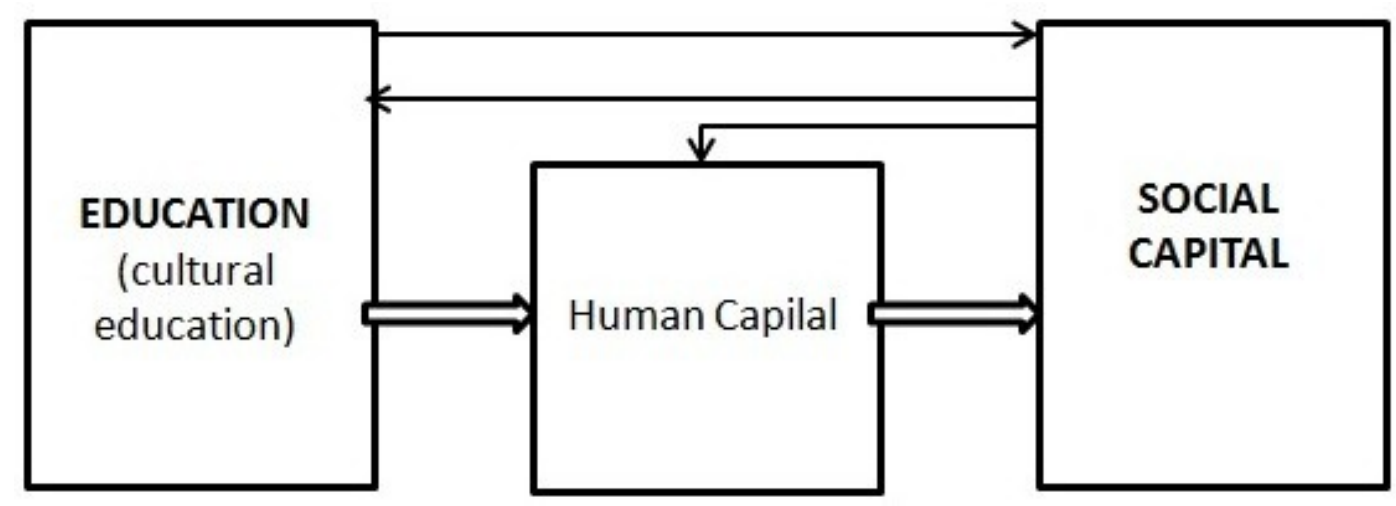

Fig. 1. The importance and the impact of education in the context of human and social capital (Source: authors' compilation).

Figure 1 shows that, originally, education (including non-formal cultural education) forms and influences the human capital, the result of which further generates the social capital. However, there is an opposite movement - feedback, social capital has a direct impact on education, as well as education has a direct impact on social capital. In the time when the human capital ties are limited in one direction, the social capital has a direct impact on education and education has an immediate impact on the social capital. The reciprocity (interaction) of education, human capital and social capital is undeniable and strong. But, at the same time, it is crucial to highlight the main differences: the human capital is impacted by the supply of education, but the social capital differs only in the matter that even though it is mainly determined by the social environment (social networks), educational opportunities that clearly put the social capital theories in a dominant position and give much wider interpretation and research opportunities are equally significant. In this context, human capital means human abilities, but social capital means people's contribution, with whom in reciprocity we are doing work and solving problems.

Although in the area of the social capital (mainly in the economic and regional development aspect) there has been many research conducted and there exists a wide theoretical basis, the most significant problem of the social capital is that there is no unity about how to evaluate it, which is dictated by its multidimensional character. Traditionally, two valuation approaches are used: counting the number of the groups and measuring the participation in them or using questionnaires and interviews to obtain data on trust and civic activities, but the results mainly have descriptive nature, based on the specifics of the social capital theory and its characteristic indicators.

By analysing the theoretical notion, it can be concluded that the social capital is a multiple element phenomenon whose measuring requires various indicators. Therefore, based on the theories used in the research, examining the analysed literature and sources (Bullen \& Onyx, 1998; Coleman, 2013; Fukuyama, 1995; Gordon \& Beilby-Orrin, 2006; Igaune, 2012; Matarasso, 2000; Reeves, 2002) in the non-formal cultural education context, the authors have developed their theoretically justified 
evaluation model of the social capital that consists of 10 elements (participation, participation in networks, interaction/reciprocity, trust, social norms, the commons, tolerance of diversity, personal empowerment, attitudes to government, demographic information) that relates to the defining of the social capital and can be used as their characterising indicators. As a result, this study offers a theorybased and developed social capital assessment model of non-formal cultural education programmes (Fig. 2).

\begin{tabular}{|c|c|c|c|c|}
\hline \multirow{11}{*}{ 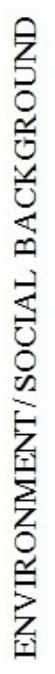 } & Indicators & Key words & \multirow{11}{*}{ 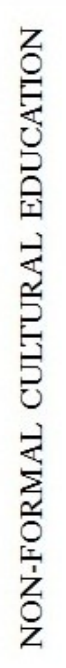 } & \multirow{10}{*}{ 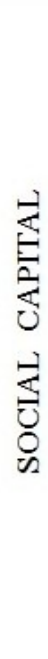 } \\
\hline & $\begin{array}{l}\text { PARTICIPATION AND } \\
\text { CONNECTION }\end{array}$ & $\begin{array}{l}\text { attendance, acting together, strengthening } \\
\text { of relationships }\end{array}$ & & \\
\hline & PARTICIPATION IN NETWORKS & $\begin{array}{l}\text { between individuals and groups; } \\
\text { voluntarism; intersection in networks }\end{array}$ & & \\
\hline & RECIPROCITY & acting for the community, altruism & & \\
\hline & $\begin{array}{l}\text { FEELINGS OF TRUST AND } \\
\text { SAFETY }\end{array}$ & mutually supportive; cause and effect & & \\
\hline & SOCIAL NORMS & mostly unwritten; acceptable to the public & & \\
\hline & THE COMMONS & combined element from several indicators & & \\
\hline & $\begin{array}{l}\text { TOLERANCE OFDIVERSITY/ } \\
\text { OPENNESS }\end{array}$ & tolerance; enlightening & & \\
\hline & $\begin{array}{l}\text { PERSONAL EMPOWERMENT/ } \\
\text { VALUE OF LIFE }\end{array}$ & core values of life and personality & & \\
\hline & ATTITUDES TO GOVERNMENT & civilconsciousness; involvement & & \\
\hline & DEMOGRAPHIC INFORMATION & sex; age & & \\
\hline
\end{tabular}

Fig. 2. Social capital analysis indicators in non-formal education (Source: authors' compilation).

By exploring the social capital theories, each of the chosen elements in figure are marked with a specific theoretical background, but often one indicator results from another and they overlap. For example, the social capital is considered as both an intersection and a link in relationships between individuals and between groups. Also participation - both individual and in groups - in the context of the social capital is closely related to trust, reciprocity, social norms and so on. For this reason, there aren't strictly defined definitions that can be brought forward for each of the indicators, but it is possible to outline the essence and view it in the context of non-formal cultural education.

The model was tested in 10 institutions subordinate to the Ministry of Culture of the Republic of Latvia analysing 37 non-formal cultural education programs during the period from October 2014 to May 2015.

\section{Conclusions}

Museums, concert halls, theatres, opera, libraries and other providers of non-formal cultural education, creating and offering its educational programmes, undoubtedly have become an integral part of public cultural education component. These programs have not only educational but also a socially important role and functions and are in constant development and interaction with significant processes in society. Non-formal cultural programmes provide an opportunity for traditional cultural institutions to ensure a new dimension to their scope and profile and help to reach cultural users in attractive and intelligible language, to attract young visitors with innovative methods.

Strengthening of the personality, which happens when an individual engages in various social activities, including non-formal cultural education programs, allows oneself to receive the benefits, such as increasing satisfaction with life, boosting potential of own intelligence and a variety of practical and creative skills. Strengthening of personality and improving the quality of life are one of the most important elements in the context of social capital. 
One of the social capital theory postulates considers that the level of trust is affected in the most direct way by the level of education. The more educated and more interested is the society, the more actively with the higher level of confidence it responds to the strengthening of social capital. So there is reciprocity between the institution and its visitors in mutual trust reinforcing direction.

Summarising the non-formal cultural education programme analysis developed by the authors' and social capital assessment model of the subordinate institutions of the LR Ministry of Culture confirms that elements of social capital such as participation, participation in networks, interaction/reciprocity and trust as contributing factors are inherent to the discussed non-formal cultural education programmes. Mentioned programmes contribute to the personal empowerment and development of the individual; promote tolerance and understanding of other cultures, tolerance of diversity, and, in certain conditions; and serve as educational and strengthening tools of social norms. However, indicators such as age, gender and attitude toward the government are not so significant in the context of non-formal cultural education. According to the theoretical model and the conclusions after the experts' interviews, it can be assumed that there is a mutual social capital and non-formal cultural education programme reciprocity amongst the observed cultural organisations and that these programmes have a positive and a contributory role in strengthening the social capital of both the individual and the society.

Practically, all of the non-formal culture education programmes of the institutions in Latvia analysed in this research are their own initiative and self-realisation. For the moment, there are no laws or regulations that would impose non-formal education in cultural institutions as a mandatory requirement. Without doubt, there is a setting that these institutions should more or less carry out an educational function, but there is no determination of the volume, depth and amount of this function in policy documents. From that it is possible to draw conclusions that previously described and analysed non-formal cultural education contribution to the education and strengthening of the society and is based on the leaders of the institution and the initiative, inspiration and creative abilities of their team. Therefore, it would be advisable to continue the research in the field of non-formal education in order to strengthen the appreciation of the acquired skills and knowledge and recognition on a national level, as well as to create a correct understanding of the significant role of non-formal education in a wider context. As there is little research about social capital in the context of Latvia, this multidimensional and important phenomenon should be promoted to be studied in all of its varieties.

Various cultural institutions, analysed in this research, have showed interest about the research results and see an opportunity to gain additional in communication with the state, local authorities, project funds and other institutions, in order to strengthen and emphasise the value of non-formal cultural education in socially significant processes.

\section{References}

Bourdieu, P. (1986). The Forms of Capital. In: John G. Richardson (Ed.) Handbook of theory and research for the sociology of education.

Bourdieu, P. (1989). Social Space and Symbolic Power. Sociological Theory, (7), 14-25.

Bullen, P. \& Onyx, J. (1998). Measuring social capital in five communities in New South Wales. Sydney, Australia: University of Technology, Center for Australian Community Organizations and Management.

Coleman, J. S. (1966). Equality of Educational Opportunity. USA: Johns Hopkins University.

Coleman, J. S. (1990). Foundations of social theory. Cambridge, Massachusetts; London (England): Belknap Press of Harvard Univ. Press.

Coleman, J. S. (2013). Social Capital in the Creation of Human Capital. In: Trust and social capital in organizations. London; Thousand Oaks, CA: Sage Publications.

Commission of the European Communities. (2000). A Memorandum on Lifelong Learning. Brussels. [Accessed 28.12.2014]. Available from Internet: http://arhiv.acs.si/dokumenti/Memorandum_on_Lifelong_Learning.pdf

Cultural Policy Guidelines 2014-2020. "Creative Latvia". (2014). [Accessed 24.03.2015]. Available from

Internet: http://polsis.mk.gov.lv/view.do?id=4877 
Daugavietis, J. (2015). Amateur arts in Latvia: community development and cultural policy. University of Latvia.

Dijkstra, A. B., Veenstra, R. \& Peschar, J. L. (2004). Social capital. functional communities around high schools in the Netherlands. In: Creation and returns of social capital: a new research program. London; New York: Routledge.

Festeu, D. \& Umberstone, B. (2006). Non - formal education through outdoor activities guide. The European Institute for Outdoor Adventure and Experiential Learning. Buckinghamshire.

Fukuyama, F. (1995). Social Capital and the Global Economy. Foreign Affairs, (5).

Glaeser, E., Laibson, D. \& Sacerdote, B. (2002). The Economic Approach to Social Capital. The Economic Journal, (112), 437-458.

Gordon, J. \& Beilby-Orrin, H. (2006). International Measurement of the Economic and Social Importance of Culture. Paris: Organisation for Economic Co-operation and Development.

Heller, P. (1996). Social Capital as a Product of Class Mobilization and State Intervention : Industrial Workers in Kerala, India. World Development, (6), 1055-1071.

Higgins, P. \& Loynes, C. (1997). On the nature of outdoor education. Scottish Natural Heritage.

Higgins, P. \& Loynes, C. (1997). Towards Consensus on the Nature of Outdoor Education. JAEOL, (4), 2-3.

Igaune, E. (2012). Sociālais kapitāls: teorija, analīze, praktiskā pielietošana. Rīga: Ekonomikas un kultūras augstskola.

Imandoust, S. B. (2011). Relationship between Education and Social Capital. International Journal of Humanities and Social Science, (12), 52-57.

Knack, S. \& Keefer, P. (1997). Does Social Capital Have an Economic Payoff? A Cross-Country Investigation. The Quarterly Journal of Economics, (4), 251-1288.

Law on Education. (1998). [Accessed 28.12.2014]. Available from Internet: http://likumi.lv/doc.php?id=50759

Lin, N. (1999). Building a network theory of social capital. Connections, (1), 28-51.

Matarasso, F. (2000). USE OR ORNAMENT? The social impact of participation in the arts. Comedia, The Round, Bournes Green, Stroud.

National Development Plan 2014-2020. (2012). [Accessed 28.12.2014]. Available from Internet: http://likumi.lv/doc.php?id=253919

Pelše, M. (2007). Sociālā kapitāla attīstības iespējas Zemgalē: promocijas darba kopsavilkums ekonomikas doktora (Dr.oec.) zinātniskā grāda iegūšanai. Jelgava: Latvijas Lauksaimniecības universitāte.

Putnam, R. D. (1993). The prosperous community. The American Prospect, (13), 35-42.

Putnam, R. D. (1996). The decline of civil society: How come? So what?. The Journal of Public Sector Management Development, (27), 27-36.

Putnam, R. D. (2000). Bowling alone: the collapse and revival of American community. New York: Simon \& Schuster

Reeves, M. (2002). Measuring the economic and social impact of the arts: a review. Arts Council England.

Smith, M. (2001). What is non-formal education? [Accessed 26.04.2015]. Available from Internet: http://www.infed.org/biblio/b-nonfor.htm\#introduction

Sustainable Development Strategy of Latvia "Latvia 2030". (2010). [Accessed 28.12.2014]. Available from Internet: http://baltadaba.lv/wp-content/uploads/2013/04/latvija2030_lv.pdf

Tzanakis, M. (2013). Social capital in Bourdieu's, Coleman's and Putnam's theory: empirical evidence and emergent measurement issues. Educate, (13), 2-23.

UNESCO. International Standard Classification of Education. [Accessed 02.03.2015]. Available from Internet: http://www.uis.unesco.org/Education/Pages/international-standard-classification-of-education.aspx

Woolcock, M. \& Deepa, N. (2000). Social Capital: Implications for Development Theory, Research, and Policy. The World Bank Research Observer, (2), 226-249. 